\title{
A FREE CASH FLOW-TÓL A SZABAD PÉNZÁRAMIG
}

A diszkontált cash flow (DCF) alapú vállalatértékelési elmélet egyik központi kategóriáját képezi a vállalat tốkejuttatói (tulajdonosai és hitelezối) által elérhetố szabad pénzáramlás, melyet az angol nyelvú szakirodalom Free Cash Flow-nak nevez. A Free Cash Flow fogalma és definíciója már régóta jelen van a magyar szakirodalomban is. $\mathrm{E}$ tanulmány megírásakor az a cél vezérelte a szerzốt, hogy az eddigiekben publikált „magyarított” modelleket kiegészítve, illetve tovább finomítva, kidolgozzon egy teljes részletezettségú, a magyar számviteli sajátosságokra épülő számítási sémát, melynek segítségével a Free Cash Flow tökéletes pontossággal meghatározható lesz a magyar számviteli kimutatásokból.

\section{Kulcsszavak: szabad pénzáramlás, Free Cash Flow, számvitel}

A vállalatértékelési eljárások között a diszkontált cash flow (DCF) koncepció mind elméleti, mind gyakorlati szempontból kiemelt szerepet tölt be. Az elméleti munkák szerzôi a DCF-eljárások legnagyobb előnyét abban látják, hogy e modellek a vállalat értékét a jövőbeli jövedelemtermelő képességból eredeztetik, és eközben számításba veszik a pénz időértékét is. Emellett több kérdőíves kutatás kimutatta, hogy a vállalati menedzserek a gyakorlati alkalmazás során is a cash flow szemléletű módszereket részesítik előnyben (pl. Graham-Harvey, 2001; Dittmann - Maug - Kemper, 2002).

A számítás során a jövốbeli időszakokra vonatkozóan azt a pénzösszeget próbáljuk megragadni, amely a vállalkozási tevékenység folytatása következtében a tulajdonosok és a hitelezők megtérülési elvárásainak (osztalék, tóketörlesztés, kamat) kielégítésére rendelkezésre áll. A szakirodalom ezt nevezi Free Cash Flownak, azaz szabad pénzáramnak, melyet a vállalkozásba befektetett tóke súlyozott átlagköltségével (Weighted Average Cost of Capital, WACC) diszkontálva megkapjuk a vállalat becsült értékét.

A Free Cash Flow definícióját és levezetését illetően a külföldi szakirodalom teljesen egységesnek mondható: olyan adózás utáni pénzáramként definiálják, melyet a vállalkozás idegen tôke használata nélkül, tisztán saját forrásból ért volna el (CopelandMurrin - Koller, 2000; Damodaran, 2001; Fernandez, 2002; Agar, 2005). Meghatározásának képletét az 1. ábra foglalja össze.
A Free Cash Flow-t az adózás és kamatfizetés elótti eredményból (Earnings Before Interest and Tax, EBIT) származtatjuk, ami azt jelenti, hogy az adózás elótti ered-

A Free Cash Flow meghatározása (Fernandez, 2002)

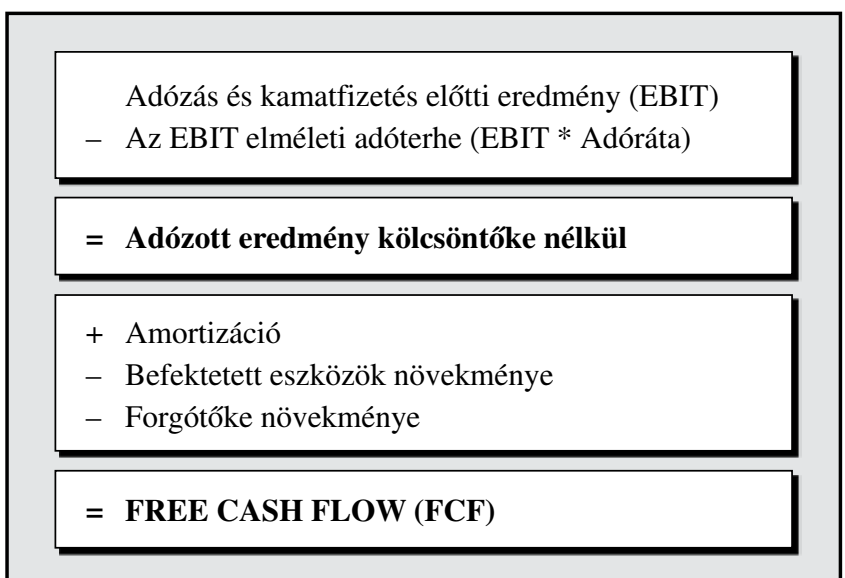

ményt a kölcsöntókével összefüggő fizetendő kamatok nélkül határozzuk meg. Az EBIT-ból az erre vetített adó (ez csak elméleti adóteher, hiszen a valós adókötelezettséget a kamatráfordításokat is tartalmazó adózás előtti eredmény alapján számítjuk) levonása után egy olyan hipotetikus adózott eredményt kapunk, amelyet a vállalkozás kölcsöntóke igénybevétele nélkül ért volna el. Ez azonban még csak számviteli eredmény, a tényleges pénzáramok számszerúsítéséhez a fent hivatkozott szerzók szerint el kell végezni néhány korrekciót: 
- Az első korrekció a tárgyévi amortizációs költségek hozzáadása, hiszen az eredményt csökkentô költségként számvitelileg számolták el, azonban nem jelent pénzkiáramlást a vállalkozásból.

- A második korrekció a befektetett eszközök állományában bekövetkezett növekmény levonása. Ennek oka, hogy a tartós eszközökbe történó beruházás számviteli szempontból nem minôsül költségnek, így az eredményben nem jelenik meg, ugyanakkor pénzkiáramlást von maga után.

- A harmadik korrekció a forgótóke növekményének levonása, ugyanis a forgótókében bekövetkezett változások a számviteli eredményben nem tükröződnek, mégis pénzmozgással járnak. Példaként említhetünk egy anyag- vagy árubeszerzést, ahol a kifizetett pénzösszeget nem költségként, hanem a készletek növekményeként mutatták ki.

A három korrekciós tétel közül kettő (az amortizációs költség és a befektetett eszközök növekménye) nem igényel különösebb magyarázatot, hiszen ezek a mérlegból és az eredménykimutatásból közvetlenül kiolvashatók. Fontosnak tartom ugyanakkor a forgótôke pontos definiálását. Ennek megkönnyítésére Fernandez a már hivatkozott cikkében a számviteli mérleg átrendezését javasolja oly módon, hogy a forgótóke közvetlenül leolvasható legyen belóle. Ezt úgy érhetjük el, hogy az eszközök oldalán a befektetett eszközök mellett a nem pénzformában meglévő forgóeszközök és a kamatteher nélküli rövid lejáratú kötelezettségek (pl. szállítói tartozások) különbségeként kiszámított forgótókét, valamint a pénzeszközöket szerepeltetjük. Következésképpen a források oldalán a saját tóke, valamint a kamattal terhelt kötelezettségek (Fernandez szerint „financing liabilities", azaz finanszírozási kötelezettségek) jelennek meg. A forgótő́ke tehát nem más, mint a pénzeszközöktól különböző forgóeszközök és a kamattal nem terhelt rövid lejáratú kötelezettségek különbsége, melyet az átalakított mérleg bal oldaláról olvashatunk le.

A korrekciós tételek figyelembevétele után eljutunk a Free Cash Flow-hoz, amely tehát azt az adózás utáni pénzáramot reprezentálja, amely a vállalkozás számára rendelkezésre áll a tulajdonosok és hitelezók megtérülési elvárásainak kielégitésére.

A Free Cash Flow fogalma a magyar szakirodalomban már a '90-es évek elején feltúnt (pl. Csécsei, 1991; Ulbert, 1994). Az ezredforduló után egyre több cikk foglalkozott a magyar rendszerre történó átfordítással, melyek közül (Dorgai, 2001) és (Kiss, 2003) munkáit emelném ki: ezekben a szerzók az angol megnevezéseket a megfeleló magyar kifejezésekkel helyettesítve vezetik le a vállalati szabad cash flow-t, melyet a 2. ábrán láthatunk.

2. ábra

A Free Cash Flow levezetése Dorgai (2001) és Kiss (2003) szerint

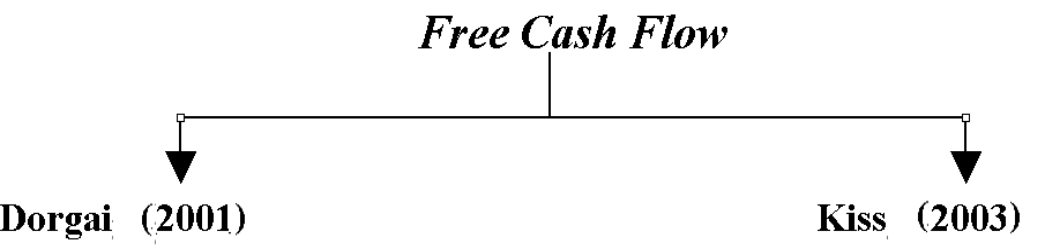
+ 1. Üzemi/üzleti tevékenység eredménye
- 2. Számított adófizetés
(Üzemi/üzleti tevékenység eredménye*(1-adókulcs))
$=$ I. Adózás utáni működési eredmény (NOPLAT) (1-2)
+ 3. Értékcsökkenési leirás és egyéb nem pénzmozgással járó tételek
$=$ II. Bruttó cash flow $(\mathrm{I}+3)$
$+/$ 4. Müködő tőke növekménye
+/- 5. Tárgyieszköz-beruházás
+/- 6. Müködési tevékenységhez szükséges egyéb eszközök és források állományváltozása
$=$ III. Bruttó befektetés $(4+5+6)$

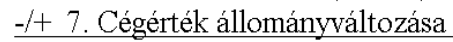
= Hitelezők és sajáttőke-tulajdonosok részére
rendelkezésre álló Szabad cash flow - FCFF
(Free Cash Flow to the Firm) (III- \pm+7 )

EBIT (kamatfizetés és adózás előtti eredmény)

- EBIT után fizetendő készpénzes adó (EBIT*(1-t))

= NOPAT (korrigált adóval csökkentett nettó múködési profit)

\pm Amortizáció és egyéb nem cash tételek

= Bruttó cash flow

土 Müködő tőke állományváltozása

$=$ Müködési cash flow

土 Egyéb eszközök egyéb forrásokkal csökkentett állományának változása

- Tőkekiadások (befektetett eszközök bővítése, „capital expenditure”, CAPEX)

= Alaptevékenység szabad cash flow-ja

土 Goodwillbe történő befektetések (goodwill változás goodwill amortizáció)

土 Rendkívüli tételek, müködéshez nem kapcsolódó

pénzáramlások

= A cég összes tulajdonosa (hitelezők is beleértve) számára rendelkezésre álló cash flow (Free Cash Flow to the Firm, FCFF) 
E levezetések felvetettek bennem bizonyos kérdéseket, melyekre saját modellem kidolgozásakor választ kívántam adni.

Az egyik fontos kérdés, hogy vajon indokolt-e a Free Cash Flow-ból a teljes pénzügyi eredményt kizárni, mint ahogy mindkét szerzőnél látható. A pénzügyi múveletek eredményét ugyanis a magyar eredménykimutatás a szokásos vállalkozási eredmény részeként határozza meg, tehát a normális, rendszeres üzletmenethez tartozónak minôsíti azt. Álláspontom szerint az eredménynek a külsố finanszírozás hatásától való megtisztításához kizárólag a fizetendó kamatokat kell figyelmen kívül hagyni, ugyanis a pénzügyi bevételek (pl. befektetések után kapott osztalék, kamat, különbözó ügyletek árfolyamnyereségei) és a fizetett kamaton kívüli pénzügyi ráfordítások (pl. különböző ügyletek árfolyamveszteségei) nem kapcsolhatók az idegen tôkéhez, hanem a vállalkozás saját tranzakcióinak eredményét mutatják. Éppen ezért e pénzáramokat véleményem szerint figyelembe kell venni a Free Cash Flow kiszámításakor.

A következő problémás pont a rendkívüli eredmény kérdése. Dorgai a rendkívüli eredményt kizárja az FCF-ból, ennek megfelelóen pedig az eszközállomány-változásokat kifejező korrekcióknál csak a múködéshez szükséges eszközöket veszi alapul. Ebből viszont az következik, hogy a modell nem általánosítható, cégenként változhat annak definíciója, hogy mi tartozik a „múködéshez szükséges eszközök” közé. Kiss modellje számol a rendkívüli eredménnyel, ugyanakkor a korrekciós tételeknél minden eszköz és forrás állományváltozását tekintetbe veszi. Ezzel a modell általánosan alkalmazható, hiszen nem igényli az eszközök szétválasztását „múköódéshez szükséges” és „,múköódéshez nem szükséges” kategóriákra. Problémát jelent viszont itt is, hogy néhány kategóriát például a „múködő tốke”, vagy az „egyéb nem cash tételeket" - nem fejtenek ki részletesen. Ugyanakkor ilyen adatok a magyar mérlegból közvetlenül nem olvashatók ki.

Amennyiben a korrekciókat a mérleg adataira támaszkodva, tehát az összes eszköz és forrás állományváltozását figyelembe véve határozzuk meg, akkor a teljes rendkívüli eredményt figyelembe kell venni annak érdekében, hogy a rendkívüli eredményt érintő, de pénzmozgással nem járó események hatásait a modell is cash-flow semlegesnek minôsítse.

Ez a gondolat egyébként a külföldi szakirodalomban is megtalálható: Bodie, Kane és Marcus szintén úgy érvelnek, hogy az EBIT-nek a külső finanszírozás hatásán kívül a teljes tárgyévi eredményt tartalmaznia kell [Bodie-Kane-Marcus, 2004].
Végül a jelenleg meglévő magyarított modellek további finomítását az is szükségessé teszi, hogy megjelenésük óta több fontos változás állt be a számviteli törvény eszközértékelési szabályokat érintố részében. Legfontosabb példaként a goodwill amortizációjának megszúnését és a valós értékelés megjelenését említeném meg.

\section{A ,magyarítás” kihívásai}

Amint korábban említettem, a Free Cash Flow fogalma eredendően amerikai szerzóktốl származik, így érthetôen az amerikai számviteli szabályokra (US GAAP) épül. Az amerikai rendszer egyik legfontosabb jellemvonása, hogy a beszámolóban szereplő számviteli kimutatásokra nincsenek szigorú formai szabályok, mindössze a rögzített keretelvek betartását kell szem előtt tartani, ettól eltekintve a vállalatok szabadon megtervezhetik mérlegük és eredménykimutatásuk felépítését. A kimutatásokban az adatok nagyon kevéssé részletezettek, csak a legfontosabb tételeket választják szét.

Ehhez képest a magyar számviteli törvény szigorúan diktált mérleg- és eredménykimutatás-sémát követel meg, melyben a tételeket megadott hierarchia szerint, nagyfokú részletességgel kell feltüntetni. Éppen ezért a korábban ismertetett ,angolszász” számítási séma a magyar szabályok fényében nagyon is szimplifikáltnak túnik, a Free Cash Flow kiszámításához cizelláltabb formula szükséges.

A magyarra adaptált modell kialakításához az alábbi adatforrásokra van szükség:

- Elózó évi és tárgyévi mérleg: a mérlegnek az Sztv. szerint két lehetséges változata van (,A” és „B” formátum), melyek közül szabadon választhat a vállalkozás. A választott formához azonban hoszszú távon tartania kell magát (következetesség elve).

- Tárgyévi eredménykimutatás: az Sztv. értelmében négy lehetséges forma közül lehet választani (összköltséges „A” és „B”, forgalmi költséges „A" és „B”). A következetesség elvét itt is alkalmazni kell.

- Analitikus nyilvántartás: a számításokhoz szükséges néhány információ sem a mérlegból, sem az eredménykimutatásból nem olvasható ki. Emiatt szükség van a vállalkozásnál vezetett részletező nyilvántartás (analitika) adataira is.

Az adaptált modell kifejtésénél mindvégig az „A” formátumú mérleget és az összköltséges „A” változatú eredménykimutatást használom fel. 


\section{Eszközértékelési szabályok a magyar számviteli rendszerben}

\section{Bekerülési érték}

Az eszközök bármilyen jogcímen történő állománynövekedése esetén meg kell határozni a bekerülési értéket, azt a forintértéket, melyen az eszközt a nyilvántartásokba beállítják. A törvény szerint ,az eszköz bekerülési (beszerzési, előállítási) értéke az eszköz megszerzése, létesítése, üzembe helyezése érdekében az üzembe helyezésig, a raktárba történő beszállításig felmerült, az eszközhöz egyedileg hozzákapcsolható tételek együttes összege" (Sztv. 47. §. [1]). A bekerülési érték tehát minden olyan ráfordítást magában foglal, amely a használatbavétel időpontjáig közvetlenül az eszköz megszerzése érdekében merült fel. A bekerülési érték beszerzési árat vagy előállítási költséget jelent. Beszerzés esetén a bekerülési érték az egyszerú vételáron túl tartalmazza a kapcsolódó szállítási, rakodási költséget, megbízási, közvetítói díjakat, biztosítási díjat, vámterheket, hitelkamatot, adókat (pl. fogyasztási adó, jövedéki adó) és minden egyéb tételt, amely egyedileg hozzákapcsolható a megszerzett eszközhöz. Saját előállítás esetén a bekerülési érték egyenlő a létrehozott eszköz tényleges közvetlen önköltségével, azaz a gyártás során kifejezetten az eszköz-előállításhoz kapcsolódóan felmerült költségek összegével.

\section{Terv szerinti értékcsökkenés}

Az immateriális javak és tárgyi eszközök jellemzője, hogy a használat során értékükból veszítenek. Ez visszavezethetố egyrészt a tényleges fizikai kopásra, valamint erkölcsi kopásra, elavulásra. Az eszköz értékének ezt a folyamatos, előre tervezhetố erodálódását nevezzük értékcsökkenésnek. Az értékcsökkenés jelenségét a számviteli nyilvántartásokban is kifejezésre kell juttatni (Sztv. 52. §.), vagyis az eszköz értékét időszakról időszakra az előre megtervezett ütemben csökkenteni kell. Az értékcsökkenés nemcsak az eszköz értékét, hanem a tárgyévi eredményt is érinti, hiszen az adott évre jutó összeget az eredménykimutatásban költségként mutatják ki (értékcsökkenési leírás, amortizáció). Nem szabad azonban elszámolni amortizációt bizonyos szellemi termékek (pl. képzőmúvészeti alkotás), goodwill, földterület, telek, erdő, valamint a még nem aktivált beruházások után.

\section{Terven felüli értékcsökkenés}

Az immateriális és tárgyi eszközök értéke nemcsak a tervezett, normálisnak tekinthető kopás, illetve avulás miatt csökkenhet, hanem olyan váratlan külsô körülmények hatására is, mint például a piaci érték nagymértékú csökkenése, vagy megrongálódás, megsemmisülés stb. Az eszköz értékét ilyenkor terven felüli értékcsökkenés elszámolásával kell a reális összegre módosítani (Sztv. 53. §.). Terven felüli értékcsökkenést kell elszámolni az alábbi esetekben:

- ha a kísérleti fejlesztéssel megvalósuló tevékenységet korlátozzák, vagy a fejlesztés eredménytelen lesz,

- ha a vagyoni értékú jog piaci értéke tartósan és jelentősen a könyv szerinti érték alá csökken, illetve ha a szerződés módosulása miatt a jog csak korlátozottan vagy egyáltalán nem érvényesíthetó,

- ha a szellemi termék piaci értéke tartósan és jelentôsen a könyv szerinti érték alá csökken, illetve ha a szellemi termék megrongálódik, megsemmisül, feleslegessé válik,

- üzleti vagy cégérték (goodwill) esetében, ha a várható megtérülésként meghatározott összeg a jövốbeli gazdasági hasznokra vonatkozó várakozások megváltozása miatt tartósan és jelentősen a könyv szerinti érték alá csökken,

- ingatlanok, múszaki gépek, egyéb gépek, valamint tenyészállatok esetében, ha a piaci érték tartósan és jelentősen a könyv szerinti érték alatt van, illetve, ha az eszköz megrongálódik, megsemmisül, feleslegessé válik, eltúnik, így nem tudja betölteni eredeti funkcióját,

- beruházások esetében, ha értékük megrongálódás, megsemmisülés, feleslegessé válás miatt tartósan és jelentősen a kimutatott könyv szerinti érték alá csökken.

A fenti meghatározások többségében szerepelt a „tartósan és jelentôsen” kifejezés. Ennek hátterében a lényegesség elve áll, melynek itt nagyon fontos szerepe van. A tartós tendencia követelménye azt jelenti, hogy a piaci értéknek az értékelés idôpontját (a mérlegkészítés napját) megelőzóen legalább egy évig a könyv szerinti érték alatt kell lennie. Azt pedig, hogy a kialakult különbözet jelentốs-e, a vállalkozás szubjektíven, a számviteli politikában foglalt értékhatár figyelembevételével állapítja meg.

A terven felüli értékcsökkenés elszámolásakor az eszközértéket a mérlegkészítéskori piaci értékig kell csökkenteni. Az elszámolt összeget az eredménykimutatásban tárgyévi ráfordításként mutatják ki. A terven felüli értékcsökkenés elszámolása továbbá megváltoztathatja a terv szerinti értékcsökkenés eredetileg tervezett ütemét. Indokolt esetben a leírandó összeg, a hasznos élettartam, illetve a maradványérték módosítható, ennek számszerú hatásait azonban be kell mutatni a kiegészítő mellékletben. 


\section{Értékvesztés}

A fentiekben kifejtettem, hogy az immateriális javak és a tárgyi eszközök értékének különböző indokok miatt beálló jelentôs esését terven felüli értékcsökkenés elszámolásával juttatjuk kifejezésre. Az érték lecsökkenése azonban nemcsak az immateriális javaknál és a tárgyi eszközöknél, hanem más eszközcsoportok esetében is bekövetkezhet. A számviteli elő́rások szerint ilyen esetekben is módosítani kell az eszköz nyilvántartás szerinti értékét, ezt azonban nem értékcsökkenésnek, hanem értékvesztésnek nevezzük (Sztv. 54-56. §.).

Értékvesztést kell elszámolni az alábbi eszközcsoportoknál:

- tartós vagy forgatási célú részesedések és hitelviszonyt megtestesító értékpapírok, tartósan adott kölcsönök, valamint tartósan lekötött bankbetétek után, amennyiben az eszköz piaci értéke, illetve a jövóben várhatóan befolyó összeg tartósan és jelentôsen a könyv szerinti érték alatt van,

- vásárolt és saját termelésú készletek esetében, ha piaci értékük tartósan és jelentôsen a könyv szerinti érték alá csökken, illetve ha megrongálódás vagy egyéb ok miatt eredeti funkciójukat nem tudják betölteni,

- követelések esetében, ha a követelés összegének jövőbeli realizálása a vevő fizetésképtelensége miatt bizonytalanná válik (kétes követelés).

A korábbiakkal összhangban az értékvesztés megállapításánál is elvárás a tartós és jelentős tendencia. Az értékvesztés mértékének meghatározásakor a mérlegkészítés napján érvényes piaci értéket, illetve a jövőben várhatóan realizálható összeget kell alapul venni. Az elszámolt összeget a tárgyévi eredménykimutatásban ráfordításként mutatják ki.

\section{Visszaírás}

A terven felüli értékcsökkenés és az értékvesztés legfontosabb jellemzóje, hogy elszámolásuk nem végleges. Amennyiben az elszámolás indoka megszúnik (például a korábban csökkenô piaci ár újra emelkedni kezd, vagy a megrongálódott eszközt megjavítják), akkor az elszámolt terven felüli értékcsökkenés, illetve értékvesztés egy részét vagy teljes egészét vissza kell írni. A visszaírás az eszköz értékének növekedését eredményezi, továbbá a tárgyévi eredménykimutatásban eredményt növelő tételként jelenik meg. A visszaírást a mérlegkészítéskor érvényes piaci érték szintjéig kell elvégezni, ugyanakkor legfeljebb csak akkora összeget lehet visszaírni, amelyet eredetileg elszámoltak.

\section{Értékhelyesbités}

A törvény bizonyos tartós eszközök esetében lehetôvé teszi a felértékelést. Ha az adott eszköz piaci értéke tartósan és jelentősen magasabb, mint a könyv szerinti érték, akkor a vállalkozás értékhelyesbítés elszámolásával az eszköz értékét felfelé módosíthatja ( $S z t v .58$. §. [5]-[8]). Az értékhelyesbítés a korábbi értékelési múveletekkel ellentétben nem kötelező, csak lehetôség. Fontos jellemzője, hogy kizárólag a teljes terven felüli értékcsökkenés, illetve értékvesztés visszaírása után számolható el. Értékhelyesbítést a vagyoni értékú jogok, a szellemi termékek, az ingatlanok és kapcsolódó vagyoni értékú jogok, a múszaki berendezések, gépek, jármúvek, az egyéb berendezések, felszerelések, jármúvek, a tenyészállatok és a befektetett pénzügyi eszközök közé sorolt tartós részesedések után lehet elszámolni.

Az értékhelyesbítés tehát növeli az eszközértéket, a felértékelésbő́l származó többletet a mérleg eszközoldalán az egyes csoportokon belül elkülönítetten mutatjuk ki (immateriális javak, tárgyi eszközök, illetve befektetett pénzügyi eszközök értékhelyesbítése címén). Az ilyesfajta felértékelés azonban az óvatosság elve miatt nem növelheti a tárgyévi eredményt (nem számolható el bevételként), ehelyett a saját tókén belül az értékelési tartalék növekedéseként kell kimutatni.

\section{Valós értékelés}

A Számviteli törvény 2004. január 1 . óta bevezette a pénzügyi instrumentum fogalmát. Pénzügyi instrumentumnak tekintendő minden „olyan szerződéses megállapodás, amelynek eredményeként az egyik félnél pénzügyi eszköz, a másik félnél pedig pénzügyi kötelezettség vagy saját tőke (tókeinstrumentum) keletkezik", különösen az adott kölcsönök, a részesedést vagy hitelviszonyt megtestesító értékpapírok, pénzeszközök és a származékos ügyletek.

A valós értékelés célja, hogy a pénzügyi instrumentumok a mérlegben a lehetô legaktuálisabb, gyakorlatilag naprakész értéket mutassák (Sztv. 59. §.). Alkalmazása nem kötelező.

Amennyiben a vállalat a törvény által felkínált lehetóséggel élve alkalmazni kívánja a valós értékelést, akkor a mérlegben szerepeltetett eszközcsoportok mellett egy másodlagos besorolást is létre kell hoznia.

Eszerint a pénzügyi eszközöket - az eredeti mérlegkategóriák érintése nélkül - másodlagosan a következó kategóriákba kell besorolni:

- kereskedési célú pénzügyi eszközök,

- értékesíthetô pénzügyi eszközök,

- lejáratig tartott pénzügyi eszközök,

- kölcsön- és más követelések. 
A pénzügyi kötelezettségeket pedig az alábbi két csoport valamelyikébe kell sorolni:

- kereskedési célú pénzügyi kötelezettségek,

- egyéb pénzügyi kötelezettségek.

A fenti másodlagos besorolásban látható típusok közül a valós értékelés kizárólag a kereskedési célú

\section{A valós értékelés szabályai}
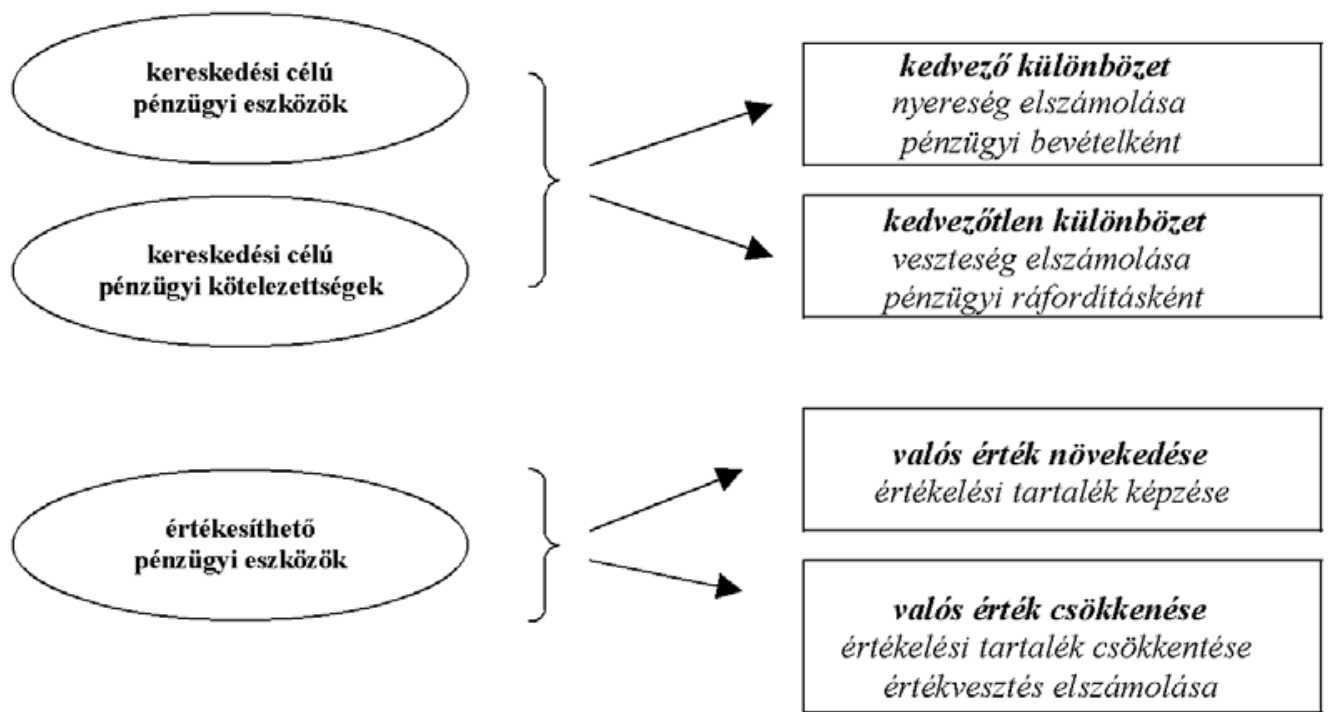

Az átalakított mérleg felépítése pénzügyi eszközökre, az értékesíthető pénzügyi eszközökre, valamint a kereskedési célú pénzügyi kötelezettségekre alkalmazható.

Ezen eszközök eredeti bekerülési értéke az aktuális valós értékre módosítható, amennyiben a valós érték megbízhatóan megállapítható. A valós érték le-, illet-

\section{3. ábra}

ve felfelé történô megváltozása a kereskedési célú pénzügyi eszközök és kötelezettségek esetében a számviteli eredményt érinti (pénzügyi múveletek bevételeként vagy ráfordításaként kerül elszámolásra), az értékesíthetô pénzügyi eszközöknél viszont a saját tôke növekményeként vagy csökkenéseként jelenik meg (3. ábra).

A fel-, illetve leértékelésekből eredő különbözetet - amellett, hogy a bemutatott módon a

4. ábra

\section{Befektetett eszközök}

(+) Immateriális javak

(+) Tárgyi eszközök

(+) Befektetett pénzügyi eszközök

\section{Forgótőke}

$(+)$ Készletek

$(+)$ Követelések

(+) Értékpapírok

(+) Aktív időbeli elhatárolások

(-) Vevőktől kapott elölegek

(-) Szállítók

(-) Kapcsolt vállalkozással szembeni, nem kamatköteles rövid lejáratú kötelezettségek

(-) Egyéb részesedésű vállalkozással szembeni, nem kamatköteles rövid lejáratú kötelezettségek

(-) Egyéb rövid lejáratú kötelezettségek

(-) Kötelezettségek értékelési különbözete

(-) Származékos ügyletek negatív értékelési különbözete

(-) Passzív időbeli elhatárolások

\section{Saját források}

(+) Jegyzett tőke

(-) Jegyzett, de még be nem fizetett töke

(+) Tőketartalék

(+) Eredménytartalék

$(+)$ Lekötött tartalék

(+) Értékelési tartalék

(+) Mérleg szerinti eredmény

(+) Céltartalékok

\section{Finanszírozási kötelezettségek}

(+) Hátrasorolt kötelezettségek

(+) Hosszú lejáratú kötelezettségek

(+) Rövid lejáratú kölcsönök

(+) Rövid lejáratú hitelek

(+) Váltótartozások

(+) Kapcsolt vállalkozással szembeni, kamatköteles rövid lejáratú kötelezettségek

(+) Egyéb részesedésű vállalkozással szembeni, kamatköteles rövid lejáratú kötelezettségek

\section{Pénzeszközök}


számviteli eredményt vagy a saját tókét módosítják - a mérlegben az eszközhöz, illetve a kötelezettséghez rendelt értékelési különbözet sorában elkülönítetten kell kimutatni (befektetett pénzügyi eszközök értékelési különbözete, követelések értékelési különbözete, értékpapírok értékelési különbözete vagy származékos ügyletek pozitív/negatív értékelési különbözete címén).

\section{A Free Cash Flow adaptált modellje}

Kétségtelen, hogy a DCF modellek magyarra történő „átfordítása" komoly kihívást jelent. Az előzőekben kifejtettem, hogy a szabad cash flow levezetése indirekt módon történik, mely során a számviteli eredményból indulunk ki, majd ezt megfelelő korrekciós tételekkel módosítjuk. A korrekciók egy része az eredménykimutatásban szerepeltetett, de pénzmozgással nem járó tételeket jelent, másik része pedig olyan mérlegváltozásokat takar, melyek a pénzállományra hatással vannak, a számviteli eredményt mégsem érintik. E korrekciók helyes értelmezésének kulcspontja a mérleg és az eredménykimutatás célszerú átalakítása, melyben a felhasznált korrekciós tételek közvetlenül jelennek meg.

\section{A mérleg átalakitása}

A mérleg átalakítását a már hivatkozott Fernandezcikk logikáját követve végeztem el. Eszerint a számviteli törvény által előírt „A” formátumú mérleget a 4. ábra szerinti formába javaslom átrendezni (4. ábra).

\section{Átalakitott mérleg}

Az átalakítás az alábbi lépéseket foglalja magában (zárójelben az előírt „A” formátumú mérleg jelölései láthatók):

1. Az eszközök oldalán a befektetett eszközök között az előírt mérlegben található kategóriákat (az immateriális javakat [A.I. sor], a tárgyi eszközöket [A.II.] és a befektetett pénzügyi eszközöket [A.III.]) mutatjuk ki, változatlan tartalommal.

Feltétlenül meg kell azonban jegyezni, hogy ezek az értékek tartalmazhatnak bizonyos, saját tókével szemben elszámolt felértékeléseket, melyek az adott eszközcsoportot növelő többletértékként, külön mérlegsorban mutatunk ki.

$\mathrm{Az}$ egyik ilyen többletérték az értékhelyesbités (immateriális javak értékhelyesbítése [A.I.7. sor], tárgyi eszközök értékhelyesbítése [A.II.7. sor], befektetett pénzügyi eszközök értékhelyesbítése [A.III.7. sor]), melynek összege a források oldalán, a saját tôkén belül, értékhelyesbités értékelési tartalékaként D.VI.1. sor is megjelenik.
A másik felértékelésból származó különbözet a befektetett pénzügyi eszközök értékelési különbözete [A.III.8. sor], amely a tartósnak minősített pénzügyi instrumentumok valós értékeléssel összefüggó felértékeléséból származik. Itt nem olyan egyértelmú a helyzet, mint az értékhelyesbítés esetében (melyet mindig a saját tókével szemben számolunk el), hiszen a felértékelés csak bizonyos esetekben történik a saját tốkével (valós értékelés értékelési tartaléka, [D.VI.2. sor]) szemben, más esetekben az összeg az eredménykimutatásban jelenik meg, a pénzügyi múveletek egyéb bevételei (17. sor) között.

A korrekciók kialakításánál kiemelt figyelmet kell szentelni ezeknek a felértékeléseknek, hiszen ezek csak elméleti eszköznövekményt testesítenek meg, ily módon pénzkiáramlás nem áll a hátterükben.

2. A forgóeszközök helyett az átalakított mérlegben a forgótókét tüntetjük fel, amely a következóket tartalmazza:

$\Rightarrow$ nem pénzformában lévő forgóeszközök (növelő tétel), úgymint

- készletek (B.I. sor),

- követelések (B.II. sor),

- forgatási célú értékpapírok (B.III. sor),

$\Rightarrow$ aktív idóbeli elhatárolások (növelő tétel) (C. sor),

$\Rightarrow$ nem finanszírozási célú (nem kamatköteles) rövid lejáratú kötelezettségek (forgótôkét csökkentő tétel), melyek közé az alábbiakat soroljuk:

- vevóktól kapott elólegek (F.III.3. sor),

- szállitók (F.III.4. sor),

- kapcsolt vállalkozással szembeni rövid lejáratú kötelezettségek (F.III.6. sor) értékébôl a nem kamatköteles összegek (ez a mérlegból nem olvasható ki, csak az analitikus nyilvántartásból állapítható meg),

- egyéb részesedési viszonyban lévó vállalkozással szembeni rövid lejáratú kötelezettségek (F.III.7. sor) értékéből a nem kamatköteles öszszegek (szintén az analitikus nyilvántartásból),

- egyéb rövid lejáratú kötelezettségek (F.III.8.),

- a rövid lejáratú kötelezettségekhez kapcsolódó, valós értékeléssel összefüggó értékelési különbözetek (F.III.9. és F.III.10. sorok),

$\Rightarrow$ passzív időbeli elhatárolások (csökkentő tétel) (G. sor).

Itt is hasonló megjegyzést tehetünk, mint a befektetett eszközök esetében. A valós értékelés szabályai ugyanis a követelésekre és az értékpapírokra is alkalmazhatók, így esetükben is megjelenhetnek olyan különbözetek, melyek az eszközök saját tőkével szembeni felértékeléséból származnak. A kö- 
vetelések értékelési különbözete (B.II.6. sor) és az értékpapírok értékelési különbözete (B.III.5. sor) összegének az a része, amelyet a saját tôkével szemben számolnak el, megtalálható a forrásoldalon (a valós értékelés értékelési tartalékában [D.VI.2. sor]), más esetekben azonban a számviteli eredményben, pénzügyi múveletek egyéb bevételeként (eredménykimutatás 17. sor) jelenik meg.

3. Az eszközök oldalán külön kategóriaként, a forgótőkétôl elkülönítetten jelenítjük meg a pénzeszközöket. Ennek legfóbb oka, hogy a cash flow korrekcióknál a nem pénzbeli forgótőke változását kell számszerüsíteni.

4. A források oldala az elóbbiekból következően egyszerúsödik. A saját források között a saját tóke mérlegben található kategóriáit tüntetjük fel, melyhez hozzákapcsoljuk még a céltartalékokat (ezek is saját forrásnak tekintendôk, hiszen a tárgyévi eredményból elkülönített összegekrôl van szó). A kötelezettségek között azonban csak az úgynevezett finanszírozási célú (kamatköteles) kötelezettségeket szerepeltetjük, amely az alábbiakat foglalja magában:

- hátrasorolt kötelezettségek (F.I. sor),

- hosszú lejáratú kötelezettségek (F.II. sor),

$\Rightarrow$ a rövid lejáratú kötelezettségek közül:

- a rövid lejáratú kölcsönök (F.III.1. sor),

- a rövid lejáratú hitelek (F.III.2. sor),

- a váltótartozások (F.III.5. sor),

- a kapcsolt vállalkozással szembeni rövid lejáratú kötelezettségek (F.III.6. sor) értékéból a kamatköteles összegek (csak az analitikus nyilvántartásból állapítható meg),

$\Rightarrow$ az egyéb részesedési viszonyban lévó vállalkozással szembeni rövid lejáratú kötelezettségek (F.III.7. sor) értékéból a kamatköteles összegek (analitikus nyilvántartás alapján).

Az így átalakított mérlegból a Free Cash Flow számításához szükséges korrekciós tételek közvetlenül leolvashatók lesznek.

\section{Az eredménykimutatás átalakítása}

Az eredménykimutatás esetében az átalakítás egyetlen célja, hogy láthatóvá tegyük az adózás és kamatfizetés elótti eredmény (EBIT) kategóriáját. A korábban kifejtett érveim alapján e ponton Bodie, Kane és Marcus álláspontját osztom, akik az EBIT-be az üzemi eredmény mellett a fizetendő kamatokon kívül a teljes pénzügyi eredményt és a rendkívüli tételeket is beleszámítják (Bodie - Kane - Marcus, 2004), úgy érvelve, hogy az EBIT-nek a külső finanszírozás hatásán kívül a teljes tárgyévi eredményt tartalmaznia kell.
Modellemben tehát az EBIT csak annyiban különbözik az adózás előtti eredménytől, hogy nem tartalmazza a tárgyévben elszámolt kamatráfordítások összegét. Az átalakított eredménykimutatás szerkezete az 5. ábrán látható (zárójelben az összköltséges „A” formájú eredménykimutatás megfelelő sorainak sorszáma látható).

5. ábra

Az átalakított eredménykimutatás

szerkezete

\begin{tabular}{|l|}
\hline Üzemi (üzleti) eredmény (A.) \\
\hline + Pénzügyi múveletek eredménye (B.) \\
\hline + Fizetendó kamatok és kamatjellegú ráfordítások (19.) \\
\hline + Rendkívüli eredmény (D.) \\
\hline = Adózás és kamatfizetés elôtti eredmény (EBIT) \\
\hline - Fizetendó kamatok és kamatjellegú ráfordítások (19.) \\
\hline = Adózás elốtti eredmény (E.) \\
\hline - Adófizetési kötelezettség (XII.) \\
\hline = Adózott eredmény (F.) \\
\hline + Eredménytartalék igénybevétele osztalékra, részesedésre (22.) \\
\hline - Jóváhagyott osztalék, részesedés (23.) \\
\hline = Mérleg szerinti eredmény (G.) \\
\hline
\end{tabular}

\section{Az átalakított eredménykimutatás}

A Free Cash Flow meghatározásakor a korábban ismertetett eredeti modellból indulunk ki. A különbséget a magyar törvény szerinti értékelési szabályok okozzák, melynek következtében jóval több korrekciós tétellel kell számolni. A modell kifejtése során $a$ fentiekben bemutatott átalakított mérleg és átalakított eredménykimutatás kifejezéseit használom.

Kiindulópontként tehát itt is az adózás és kamatfizetés elótti eredményt (EBIT) vesszük alapul, melyből le kell vonni az ehhez kapcsolódó (elméleti) adókötelezettséget. Az elméleti adóteher számításakor - a pontos adaptáció érdekében - a társasági adótörvényben (1996. évi LXXXI. törvény) foglalt adóalap-módosító tételektôl sem tekintek el. Emiatt az EBIT adóterhét az EBIT társasági adókulccsal történô egyszerú megszorzása helyett az eredménykimutatásban kimutatott (az adóalap-korrekciót is tartalmazó) adókötelezettségból származtatom úgy, hogy ahhoz hozzáadom a fizetett kamatok okozta adópajzs összegét.

Az EBIT és a számított elméleti adóteher különbségeként tehát megkapjuk a kölcsöntóke nélküli adózott eredményt, melyet megfelelő korrekciós tételekkel módosítani kell. Elsôként bemutatom a legrészletesebb, tisztán elméleti megközelítést, melyet azután felírok egy jelentősen leegyszerúsített formában is. A korrekciókat a következóképpen foglalom össze: 
- befektetett eszközök növekménye (a tárgyévben elszámolt terv szerinti és terven felüli értékcsökkenés, értékvesztés, visszaírás, valamint a saját tókével szemben elszámolt felértékelések hatása nélkül): A vállalkozás által beszerzett tartós eszközök pénzkiáramlást testesítenek meg, amely az eredménykimutatásban költségként nem jelenik meg. Ellenkező esetben, ha a vállalkozás a tartós eszközök valamelyikét értékesíti, akkor a számviteli eredményben csak az értékesítés nyeresége vagy vesztesége kerül kimutatásra, miközben pénzbeáramlásként a teljes eladási ár jelentkezik. Emiatt szükség van egy cash flow-csökkentố korrekcióra. A növekményt tehát tisztán a bruttó érték növekményeként definiáljuk (amely a tárgyévi új beruházások értékét hivatott kifejezni), azaz nem vesszük figyelembe a tárgyévben elszámolt terv szerinti és terven felüli értékcsökkenés, értékvesztés, visszaírás, valamint a saját tókével szemben kimutatott felértékelések hatásait - ezeket az öszszegeket önálló korrekciós tételnek tekintjük.

- forgótóke növekménye (a tárgyévben elszámolt értékvesztés, visszaírás, valamint a saját tókével szemben kimutatott felértékelések hatása nélkül): $\mathrm{Az}$ átalakított mérlegben definiált forgótốke (a nem pénzformában lévő forgóeszközök és az aktív idốbeli elhatárolások, valamint a nem kamatköteles rövid lejáratú kötelezettségek és a passzív időbeli elhatárolások különbsége) növekménye szintén nem jelenik meg az eredménykimutatásban, ugyanakkor pénzmozgást reprezentál, tehát cash flow-csökkentő korrekcióként kell számításba venni. A növekményt itt is a tárgyévben elszámolt értékvesztés, visszaírás és a saját tốkével szemben elszámolt felértékelések hatása nélkül kell megállapítani, mivel ezeket külön korrekcióként kezeljük.

- tárgyévben elszámolt terv szerinti értékcsökkenés (amortizáció): Az immateriális és tárgyi eszközök elhasználódását, elavulását kifejező, előre tervezhetố ütemú költség, amely a számviteli eredményben az EBIT-et csökkentố tételként került kimutatásra, ugyanakkor pénzformában nem került kifizetésre. Hatásának semlegesítése érdekében cash flow-növelő korrekciót kell végezni.

- tárgyévben elszámolt terven felüli értékcsökkenés, értékvesztés: Amennyiben az eszköz értéke valamilyen rendkívüli külső körülmény (a piaci érték jelentốs lecsökkenése, megrongálódás, megsemmisülés stb.) hatására ugrásszerúen leesik, azt a számviteli nyilvántartásokban is rögzíteni kell. Ezt az eszközérték-csökkenést az immateriális javak és tárgyi eszközök esetén terven felüli értékcsökkenés, egyéb eszközöknél pedig értékvesztés elszámolásával kell érvényesíteni. A terven felüli értékcsökkenés és az értékvesztés a magyar eredménykimutatásban az egyéb ráfordítások között jelenik meg, kivéve az értékpapírok értékvesztését, melyet a pénzügyi múveletek ráfordításai között számolunk el. Ezen eszközcsökkenéseket tehát a terv szerinti értékcsökkenéshez hasonlóan az EBIT-et csökkentő tételként kell elszámolni, de pénzkiáramlással nem jártak, így ismét cash flow-növelő korrekciót kell végeznünk.

- visszaírás: A terven felüli értékcsökkenés és az értékvesztés elszámolása nem végleges, az elszámolás indokának megszúnése esetén (a piaci érték újra jelentősen felemelkedik, a megrongálódott eszközt megjavítják stb.) vissza kell írni. A visszaírás összegét a számvitelben bevételként (EBIT-et növelő tételként) számoljuk el, pénzbeáramlás azonban nincs a háttérben, így ez esetben cash flow-csökkentő korrekciót kell végrehajtani.

A Free Cash Flow meghatározása a fentiekból kiindulva a következő:

EBIT (adózás előtti eredmény + fizetendő kamatok)

- EBIT elméleti adóterhe

(elszámolt adókötelezettség + fizetendő kamatok * társasági adókulcs)

\section{= Adózott eredmény kölcsöntóke nélkül}

- Befektetett eszközök növekménye (a tárgyévben elszámolt terv szerinti és terven felüli értékcsökkenés, értékvesztés, visszaírás, valamint a saját tókével szemben kimutatott felértékelések hatása nélkül)

- Forgótốke növekménye (a tárgyévben elszámolt értékvesztés, visszaírás, valamint a saját tốkével szemben kimutatott felértékelések hatása nélkül)

+ Tárgyévben elszámolt terv szerinti értékcsökkenés

+ Tárgyévben elszámolt terven felüli értékcsökkenés

+ Tárgyévben elszámolt értékvesztés

- Tárgyévben elszámolt visszaírás

\section{= FREE CASH FLOW}

E képlet alkalmazása kizárólag az analitikus nyilvántartás adatainak ismeretében lehetséges, hiszen a befektetett eszközök és a forgótóke tiszta növekménye, továbbá az értékeléssel kapcsolatban elszámolt összegek a mérlegból és az eredménykimutatásból nem olvashatók ki maradéktalanul. Észre kell venni azonban, hogy - mivel az eszközök növekményét egyszer a terv szerinti és terven felüli értékcsökkenés, az értékvesztés és a visszaírás hatása nélkül állapítottuk meg, majd eze- 
ket külön korrekciós tételként szerepeltettük - ugyanezt az eredményt kapnánk akkor, ha a kölcsöntóke nélküli adózott eredményt az eszközök könyv szerinti értékének növekményével korrigálnánk. Ez ugyanis már magában foglalja az összes tárgyévben elszámolt értékcsökkenés, értékvesztés és visszaírás hatását.

Ki kell emelni azonban, hogy a könyv szerinti érték nem azonos az átalakított mérleg „Befektetett eszközök”, illetve „Forgótóke” soraival, hiszen ezek tartalmazhatnak olyan felértékeléseket (immateriális, tárgyi és befektetett pénzügyi eszközök esetében értékhelyesbitést, pénzügyi instrumentumoknál értékelési különbözetet), melyek a saját tókével szemben kerültek elszámolásra, ily módon az EBIT-et nem érintik. Az eszközök könyv szerinti értékének növekményét tehát a mérlegérték növekményének és a saját tókével szemben elszámolt felértékelések növekményének különbségeként határozhatjuk meg.

Mindezek szemléltetésére egy példa: Tegyük fel, hogy a vállalkozás tárgyi eszközeinek mérlegben szereplő értéke bázisévben a következóképpen alakult:

Bázisévi könyv szerinti (nettó) érték $\quad 8450$

+ Bázisévi halmozott értékhelyesbítés $\quad 1320$

= Bázisévi mérlegérték

9770

A tárgyévben ugyanezen eszközökkel kapcsolatban az alábbi összegeket számolták el:

- új beruházás

- meglévő tárgyi eszközök tárgyévi terv szerinti értékcsökkenése

- irodai berendezésekre elszámolt terven felüli értékcsökkenés

1800

- múszaki gépek korábbi terven felüli értékcsökkenésének visszaírása

- ingatlanokra elszámolt értékhelyesbítés

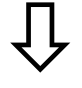

Tárgyévi könyv szerinti (nettó) érték: $8450+1800-930-400+280=$

+ Tárgyévi halmozott értékhelyesbítés: $1320+560=$

560

= Tárgyévi mérlegérték 1880

Ezen adatok alapján a Free Cash Flow meghatározásakor a kölcsöntôke nélküli adózott eredményt (EBIT-elméleti adóteher) a következő tételekkel kellene korrigálnunk:

- Bruttó érték tárgyévi növekménye

+ Tárgyévi terv szerinti értékcsökkenés

+ Tárgyévi terven felüli értékcsökkenés

- Tárgyévi visszaírás

1800

930

400

280

$\Sigma$ Korrekciók együttes hatása

$-750$
A korrekciók együttes hatása megegyezik a nettó érték növekményével $(9200-8450=750)$. A mérleg „Tárgyi eszközök" sorában azonban nem a nettó érték, hanem az értékhelyesbítést is tartalmazó mérlegérték jelenik meg. A fenti számítás így a következóvel lenne helyettesíthető:

- Mérlegérték növekménye: 11 080-9 770 = 1310

+ Értékhelyesbítés növekménye: 560

$\Sigma$ Korrekciók együttes hatása $-750$

Ugyanez a folyamat levetíthetô a többi eszközcsoportra is. Az immateriális javaknál ugyanezekkel a tételekkel kell számolni, a befektetett pénzügyi eszközök és a forgótốke esetében pedig a terven felüli értékcsökkenés helyett az értékvesztés jelenik meg, továbbá az értékhelyesbítés helyett/mellett a felértékelés másik típusát, az értékelési különbözetet kell kezelnünk.

Nagyon fontos megjegyzés, hogy míg az értékhelyesbités minden esetben a saját tókével szemben kerül elszámolásra, a pénzügyi instrumentumok értékelési különbözete csak részben növeli a saját tókét, más esetekben pénzügyi bevételként (tehát EBIT növekményként) kerül elszámolásra. A befektetett eszközöknél és a forgótókénél kimutatott értékelési különbözetekból az analitikus nyilvántartás nélkül nem lehet szétválasztani a saját tókével szemben és az EBIT-tel szemben elszámolt összegeket. E probléma legkézenfekvőbb megoldása az, hogy a különbözetet az eszközoldal helyett a forrásoldalról közelítjük meg. A számviteli törvény ugyanis rögzíti, hogy a saját tôkével szembeni felértékeléseket minden esetben az értékelési tartalékban kell kimutatni, így a korrekcióknál az eszközök mérlegértékének növekményét az értékelési tartalék növekményével kell ellensúlyozni (6. ábra).

Ez a modell általánosan alkalmazható a már lezárt számviteli időszakok Free Cash Flow-jának pontos meghatározására a beszámolóban lévố kimutatások alapján, de a számítási elvet a jövőre kivetítve előrejelzéseket is készíthetünk a jövőre vonatkozóan, ezzel pedig lehetőség nyílik a vállalat diszkontált cash flow alapú értékének megbecslésére.

\section{Az adaptált modell jelentôsége,újdonságtartalma}

A fentiekben levezetett adaptált modellem több ponton is újdonságtartalommal bír a magyar szakirodalomban eddig megjelent írásokhoz képest. A hivatkozott múvekben ([Dorgai, 2001] és [Kiss, 2003]) közölt levezetésekhez viszonyítva formai és tartalmi oldalról is több módosítást javaslok.

Formai oldalról közelítve modellem jelentôsége abban áll, hogy egy olyan számítási sémát kínál az értékelő́k számára, amely a magyar számviteli szabályok szerint összeállított beszámoló adatainak közvetlen fel- 


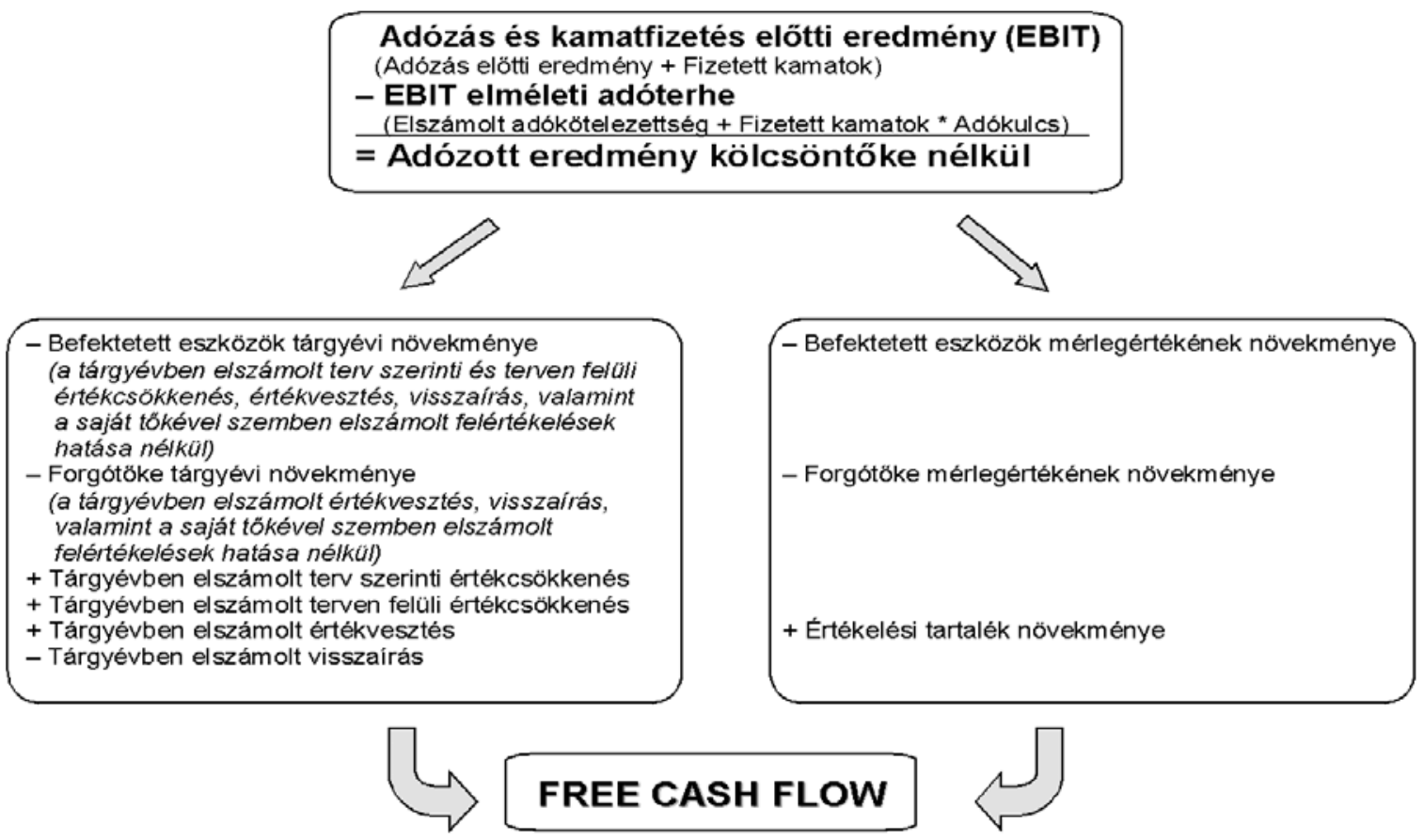

használásával lehetőséget nyújt a szabad pénzáram tökéletesen pontos meghatározására. Mindeközben a magyar számviteli törvényben foglalt eszközértékelési szabályokat teljeskörúen figyelembe veszi, továbbá a benne foglalt kategóriák egyértelmúen megfeleltethetôk a magyar mérleg és eredménykimutatás tartalmi elemeinek. Mindez meggyőződésem szerint a korábbiakban publikált levezetésekre nem, vagy csak részben volt jellemző.

Modellem két ponton tartalmilag is eltér az eddigiekben közölt levezetésektól. Egyrészt vitatom azt a nézetet, miszerint az EBIT-et az üzemi (üzleti) eredménnyel kell azonosítani. Álláspontom szerint ugyanis a tényleges adózás és kamatfizetés elótti eredmény meghatározásához az üzemi eredményen túl a kamatráfordítások kivételével valamennyi pénzügyi és rendkívüli tételt figyelembe kell venni. Eltérố módon közelítem meg az EBIT adóterhét is, hiszen az eddigi írásokkal szemben nem tekintek el a magyar társasági adótörvényben foglalt adóalap-korrekciós tételek hatásától sem.

Az adaptált modellt kifejezetten a magyar számviteli rendszer sajátosságai alapján alakítottam ki, így alkalmazásával teljes pontossággal kiszámítható lesz a tulajdonosok és hitelezók számára rendelkezésre álló pénzeszközök mennyisége, azaz valóban eljuthatunk a szabad pénzáramig.

\section{Felhasznált irodalom}

1996. évi LXXXI. törvény a társasági adóról és osztalékadóról 2000. évi C. törvény a számvitelról
Agar, C. (2005): Capital Investment \& Financing: A Practical Guide to Financial Evaluation, Elsevier ButterworthHeinemann, Oxford

Bodie, Z. - Kane, A. - Marcus, A.J. (2004): Essentials of Investments, McGraw Hill Irwin, New York

Copeland, T. - Murrin, J. - Koller, T. (2000): Valuation: Measuring and Managing the Value of Companies, 3rd Edition, Wiley, Chichester

Csécsei R. (1991): Vállalatértékelés, Ipar-Gazdaság, január

Damodaran, A. (2001): Corporate Finance: Theory and Practice, 2nd edition, John Wiley \& Sons, Chichester

Dittmann, I. - Maug, E. - Kemper, J. (2002): How Fundamental are Fundamental Values? Valuation Methods and Their Impact on the Performance of German Venture Capitalists, School of Business and Economics, Institut für Konzernmanagement, Berlin

Dorgai I. (2001): A részvényesi értékmaximalizálás elméleti háttere, Múhelytanulmány (6. sz.), BKÁE, október

Fernandez, P. (2002): Company Valuation Methods. The most common errors in valuations, Research Paper No. 449, IESE University of Navarra, January

Graham, J.R. - Harvey, C.R. (2002): The theory and practice of corporate finance: evidence from the field, Journal of Financial Economics

Kiss L. (2003): Vállalatértékelés egyszerúen, megbízhatóan: A vállalatértékelés módszertana (3. fejezet), Fórum Média Kiadó, március

Ulbert, J. (1994): A vállalat értéke, JPTE Közgazdaságtudományi Kar, Pécs

Cikk beérkezett: 2007. 10. hó

Lektori vélemény alapján véglegesítve: 2008. 4. hó 